\title{
Observations of the uptake of carbonyl sulfide (COS) by trees under elevated atmospheric carbon dioxide concentrations
}

\author{
L. Sandoval-Soto ${ }^{1, *}$, M. Kesselmeier ${ }^{3}$, V. Schmitt ${ }^{2}$, A. Wild ${ }^{2}$, and J. Kesselmeier ${ }^{1}$ \\ ${ }^{1}$ Max Planck Institute for Chemistry, Biogeochemistry Department, Hahn-Meitner-Weg 1, 55128 Mainz, Germany \\ ${ }^{2}$ Institute for General Botany, University of Mainz, Müllerweg 6, 55128 Mainz, Germany \\ ${ }^{3}$ Institute of Medical Biometry and Informatics, Univ. of Heidelberg, Im Neuenheimer Feld 305, 69120 Heidelberg, Germany \\ *now at: Hochschule für Life Sciences FHNW, Gründenstrasse 40, 4132 Muttenz, Switzerland
}

Correspondence to: J. Kesselmeier (j.kesselmeier@mpic.de)

Received: 17 January 2012 - Published in Biogeosciences Discuss.: 23 February 2012

Revised: 5 July 2012 - Accepted: 6 July 2012 - Published: 3 August 2012

\begin{abstract}
Global change forces ecosystems to adapt to elevated atmospheric concentrations of carbon dioxide $\left(\mathrm{CO}_{2}\right)$. We understand that carbonyl sulfide (COS), a trace gas which is involved in building up the stratospheric sulfate aerosol layer, is taken up by vegetation with the same triad of the enzymes which are metabolizing $\mathrm{CO}_{2}$, i.e. ribulose-1,5bisphosphate carboxylase/oxygenase (Rubisco), phosphoenolpyruvate carboxylase (PEP-Co) and carbonic anhydrase (CA). Therefore, we discuss a physiological/biochemical acclimation of these enzymes affecting the sink strength of vegetation for COS. We investigated the acclimation of two European tree species, Fagus sylvatica and Quercus ilex, grown inside chambers under elevated $\mathrm{CO}_{2}$, and determined the exchange characteristics and the content of CA after a 1-2 yr period of acclimation from $350 \mathrm{ppm}$ to $800 \mathrm{ppm} \mathrm{CO}_{2}$. We demonstrate that a compensation point, by definition, does not exist. Instead, we propose to discuss a point of uptake affinity (PUA). The results indicate that such a PUA, the CA activity and the deposition velocities may change and may cause a decrease of the COS uptake by plant ecosystems, at least as long as the enzyme acclimation to $\mathrm{CO}_{2}$ is not surpassed by an increase of atmospheric COS. As a consequence, the atmospheric COS level may rise causing an increase of the radiative forcing in the troposphere. However, this increase is counterbalanced by the stronger input of this trace gas into the stratosphere causing a stronger energy reflection by the stratospheric sulfur aerosol into space (Brühl et al., 2012). These data are very preliminary but may trigger a discussion on COS uptake acclimation to foster measurements with modern analytical instruments.
\end{abstract}

\section{Introduction}

Aside from sulfur dioxide $\left(\mathrm{SO}_{2}\right)$, carbonyl sulfide (COS) is the most abundant sulfur gas in the atmosphere with relative constant mixing ratios of $450-500 \mathrm{ppt}$ and a lifetime of more than two years (Khalil et al., 1984; Mihalopoulos et al., 1991; Bandy et al., 1992; Barnes et al., 1994; Kjellström, 1998; Montzka et al., 2007; Barkley et al., 2008). Due to this long lifetime, COS can be transported up into the stratosphere where it contributes to stratospheric ozone chemistry (Crutzen, 1976; Andreae and Crutzen, 1997). In times of low volcanic activity, COS may serve as a source of sulfur to the stratospheric aerosol layer by conversion to sulfuric acid (Junge et al., 1961; Crutzen, 1976), contributing to the backscattering of radiation energy into space. Thus, the stratospheric cooling effect by the COS derived sulfate particles can be regarded to approximately cancel the warming tendency as caused by the direct radiative forcing by the trace gas COS within the troposphere (Brühl et al., 2012).

The global budget of COS has been estimated as being balanced within the ranges of uncertainties (Watts, 2000; Kettle et al., 2002). However, this balance is a matter of debate both for the sources and the sinks, especially with regard to terrestrial vegetation which acts as the main sink for this trace gas and which is reported to be heavily underestimated (Notholt et al., 2003; Mu et al., 2004; Sandoval-Soto et al., 2005; Campbell et al., 2008; Suntharalingam et al., 2008; Van Diest and Kesselmeier, 2008). This is valid for the Northern Hemisphere, whereas the Southern Hemisphere seems to be strongly influenced by the oceans (Montzka et al., 2007). 
The biological background for the uptake of COS by vegetation is understood to be the combined action of the carboxylation enzymes Ribulose-1,5-bisphosphate carboxylaseoxygenase (Rubisco; EC 4.1.1.39), Phosphoenolpyruvate Carboxylase (PEP-Co; EC 4.1.1.31) and the key enzyme carbonic anhydrase (CA; EC 4.2.1.1), which were previously reported to be involved in the exchange of carbon dioxide $\left(\mathrm{CO}_{2}\right)$ and carbonyl sulfide (COS) (Protoschill-Krebs and Kesselmeier, 1992; Protoschill-Krebs et al., 1995, 1996; Schenk et al., 2004; Yonemura et al., 2005; Notni et al., 2007). This enzymatic model consisting of three enzymes assigns a key role for CA and has been confirmed very recently by Stimler et al. (2011). Furthermore, the close relationship between $\mathrm{COS}$ and $\mathrm{CO}_{2}$ uptake enhances discussions to use COS as a tracer for canopy photosynthesis, transpiration and stomatal conductance (Wohlfahrt et al., 2012; Seibt et al., 2010). The role of CA has also been demonstrated in cases of lichens and soils (Kesselmeier et al., 1999; Kuhn and Kesselmeier, 2000; Van Diest and Kesselmeier, 2008), thus demonstrating the dominant role of this enzyme which is obviously also responsible for the toxicity of inhaled COS due to metabolization to hydrogen sulfide (Thiess et al., 1968; Chengelis and Neal, 1980). Of special interest within this context are recent findings about the identification of a $\mathrm{CS}_{2}$ hydrolase acting similarly to carbonic anhydrase by splitting $\mathrm{CS}_{2}$ into $\mathrm{H}_{2} \mathrm{~S}$ and $\mathrm{CO}_{2}$ in a thermophilic Archeon obtaining energy from reduced sulfur compounds (Smeulders et al., 2011).

Changes in the enzyme's activities will have consequences for the exchange of $\mathrm{CO}_{2}$ and $\mathrm{COS}$ between plants and the atmosphere. Elevated atmospheric $\mathrm{CO}_{2}$ can cause an immediate increase of photosynthetic $\mathrm{CO}_{2}$ uptake. However, on a long-term basis this initial stimulation of photosynthesis is often followed by a decline which is obviously caused by a decrease in activities of the carboxylating enzymes Rubisco, PEP-Co and CA. Acclimation of Rubisco is well established (Drake et al., 1997; Moore et al., 1999; Stitt and Krapp, 1999; Possell and Hewitt, 2009), though the mechanism of this kind of acclimation is a matter of debate (Rogers and Ellsworth, 2002). A decrease of Rubisco and PEP-Co activities would lead to a loss of COS uptake capacity by these enzymes. In contrast, fewer reports are available for CA, though an acclimation of the key enzyme CA might have even stronger impact. High $\mathrm{CO}_{2}$ levels caused a decrease of CA activity in cucumber (Peet et al., 1986) and cotton (Chang, 1975). An increase of the CA mRNA steady state level was found in Arabidopsis (Cervigni et al., 1971), whereas enzyme activities and their transcript levels were reduced in pea plants grown under elevated $\mathrm{CO}_{2}$ (Majeau and Coleman, 1996). These observations are in close accordance with Sage (2002), who reported about a potential reduction of the CA gene transcription. Also, the green alga Chlamydomonas reinhardtii adapts its CA activity to an increase in the environmental $\mathrm{CO}_{2}$ level with a decrease in the enzyme activity (Spencer et al., 1983; Coleman et al., 1984; Protoschill-Krebs et al.,
1995). Long-term observations, however, are not known to us. Besides enzymatic acclimation, a reduction of stomatal conductivity under long-term elevated $\mathrm{CO}_{2}$ enrichment also contributes to the acclimation of photosynthesis (Herrick et al., 2004). Thus, the growth of plants under elevated $\mathrm{CO}_{2}$ may cause an acclimation to the $\mathrm{CO}_{2}$ availability by reducing the stomatal uptake as well as enzymatic activities. Reduction of stomatal apertures will seriously affect the deposition of COS which is taken up through the stomata (SandovalSoto et al., 2005). A decrease in the CA activities as a consequence of elevated $\mathrm{CO}_{2}$ will affect the metabolic $\mathrm{COS}$ consumption by plants, as demonstrated earlier with the green alga Chlamydomonas reinhardtii which adapts to high $\mathrm{CO}_{2}$ levels by decreasing its CA activity (Protoschill-Krebs et al., 1995).

In view of our knowledge as briefly reviewed above, we may postulate the hypothesis that elevated $\mathrm{CO}_{2}$ in the long term will lead to a decrease of enzymatic activities and thus to a shift of potential compensation points, which reflect the ambient concentration at which the consumption balances production resulting in a net flux of zero (Kesselmeier and Merk, 1993; Conrad, 1994; Lehmann and Conrad, 1996; Simmons et al., 1999; Conrad and Meuser, 2000). Elevated $\mathrm{CO}_{2}$ will trigger a decrease of the enzymatic activities, which is balanced by a higher $\mathrm{CO}_{2}$ availability. Thus, the $\mathrm{CO}_{2}$ uptake may not decline, but a CA acclimation may lead to a reduction of the COS uptake due to a lower metabolic sink as long as the uptake is not also enhanced by higher substrate (i.e. COS) concentration. Furthermore, increased $\mathrm{CO}_{2}$ without an increase of COS may lead to a competitive inhibition of the COS consumption. Thus, changes in the COS uptake capacity should become visible in a shift of a potential compensation points. Therefore, we investigated the acclimation of two European tree species, Fagus sylvatica and Quercus ilex, grown inside chambers under elevated $\mathrm{CO}_{2}$, and determined the exchange characteristics and the content of CA after a 1-2 yr period of acclimation from $350 \mathrm{ppm}$ to $800 \mathrm{ppm}$ $\mathrm{CO}_{2}$.

\section{Materials and methods}

\subsection{Plant material and growth}

The tree species (3-4 yr old) investigated were holm oak (Quercus ilex L.) and European beech (Fagus sylvatica L.). From March 1998 to February 2000, the trees were grown in a greenhouse at $25^{\circ} \mathrm{C}$ under a $12 / 12 \mathrm{~h}$ light-dark regime with a light intensity of $600 \mu \mathrm{mol} \mathrm{m} \mathrm{m}^{-2} \mathrm{~s}^{-1}$ of photons (PAR) and a relative humidity of $70 \% . \mathrm{CO}_{2}$ concentrations were adjusted using pure $\mathrm{CO}_{2}$ from commercially available cylinders and held constant at $800 \mathrm{ppm} \mathrm{CO} 2( \pm 20 \mathrm{ppm})$ or at about $350 \mathrm{ppm}$ (with some variation between 330 to $450 \mathrm{ppm}$ ). For details see Peuser et al. (1995) and Peuser and Wild (1996). Three individuals of each tree species were investigated. 


\subsection{Enclosure system (cuvettes) and gas exchange measurements}

Measurements of COS exchange were time consuming and had to be spread over several days up to a few weeks. Table 1 gives an overview of the measurement schedule in order to note potential seasonal effects.

Gas exchange of enclosed tree branches (6-10 leaves) was investigated using a dynamic (flow-through) Teflon film cuvette system consisting of a plant measuring and an empty reference cuvette with 91 of volume each. The Teflon FEP film $(0.05 \mu \mathrm{m}$ thickness) was obtained from Norton SaintGobain performance plastic (Germany). This cuvette system has been operated in previous studies (Schäfer et al., 1992; Kesselmeier et al., 1993, 1996; Kuhn et al., 2000; SandovalSoto et al., 2005). The system was designed for measurements of volatile organics and sulfur compound gas exchange in the laboratory as well as in the field, and to have minimal effects on such trace gases. All experiments were performed inside a climate chamber with identical conditions as compared to the growth chamber. Trace gas sampling was accompanied by measurements of ambient $\mathrm{CO}_{2}, \mathrm{CO}_{2}$ exchange and transpiration by an infra-red gas analyzer (LiCor 6262, LiCor Inc., Lincoln, Nebraska, USA). Transpiration rates and $\mathrm{CO}_{2}$ exchange were calculated based on the concentration differences between the outlet ports of the branch cuvette and the empty cuvette (see below). Stomatal conductances were calculated according to von Caemmerer and Farquhar (1981) with cuvette air temperatures assigned as leaf temperatures.

$\mathrm{COS}$ and $\mathrm{CO}_{2}$ mixing ratios were adjusted by mixing purified compressed air gas mixtures derived from a permeation device (Haunold, Germany) with COS permeation tubes (VICI Metronics, Santa Clara, California) and $\mathrm{CO}_{2}$ from a pressurized bottle (Messer-Griesheim, Germany). For details see Sandoval-Soto et al. (2005). COS concentrations were adjusted between $230-1700 \mathrm{ppt}\left(10-70 \mathrm{nmol} \mathrm{m}^{-3}\right)$.

COS was quantified by an automated in situ analysis of volatile sulfur gases by real time sampling at both cuvettes according to von Hobe et al. (2008). With a home built automated Sulfur Gas Analyser (SUGAR), sulfur compounds were cryogenically trapped, thermally desorbed and analyzed by gas-chromatographic separation and flamephotometric detection.

Gas exchange rates $(F)$ were calculated according to Eq. (1)

$F=\Delta c(Q / A)$

considering the concentration differences between the sample and reference cuvette $\left(\Delta c=c_{\mathrm{sample}^{-}}-c_{\mathrm{ref}} ;\left[\mathrm{pmol} \mathrm{m}{ }^{-3}\right]\right)$ and the chamber flush rate $\left(Q ;\left[\mathrm{m}^{-3} \mathrm{~s}^{-1}\right]\right)$. All exchange rates were related to the enclosed leaf area $\left(A ;\left[\mathrm{m}^{2}\right]\right)$. Leaf area was determined by a calibrated scanner system (ScanJET IICX with DeskSCAN II; both Hewlett-Packard, USA), and SIZE 1.10 (Müller, Germany). For details see SandovalSoto et al. (2005).

\subsection{Determination of carbonic anhydrase activity}

Carbonic anhydrase (CA) activity was determined in leaf homogenates (leaf extracts) by an electrometric technique according to Wilbur and Anderson (1948). This method measured the $\mathrm{pH}$ drop caused by the catalytically driven $\mathrm{CO}_{2}$ dissociation at $0{ }^{\circ} \mathrm{C}$. The $\mathrm{CA}$ activity was given in dimensionless units according to Porter and Grodzinski (1983) comparing the speed of the $\mathrm{pH}$ decrease with and without the enzyme (leaf extract).

\subsection{Statistical analysis}

The linear relationship between substrate availability and the uptake rates was assessed statistically by the analysis of the Pearson's correlation coefficient relating the COS concentration in the reference cuvette to the exchange rate. Further information was obtained regarding the $R^{2}$ of the regression analysis of the linear model

$\boldsymbol{F}=\beta_{0}+\beta_{1} \boldsymbol{c}_{\mathbf{R}}+\boldsymbol{\varepsilon} \quad($ Model 1)

with $\boldsymbol{F}$ and $\boldsymbol{c}_{\mathbf{R}}$ indicating the exchange rate (dependent variable) and reference cuvette concentration of COS (independent variable), respectively. $\beta_{0}$ and $\beta_{1}$ reflect the regression coefficients and $\varepsilon$ the residuals.

For further analysis, the linear model was extended by introducing the $\mathrm{CO}_{2}$ concentration under which the trees were growing during the experiment $\left(\boldsymbol{C O}_{2}\right)$ accompanied by the interaction between $\boldsymbol{c}_{\mathbf{R}}$ and $\boldsymbol{C O}_{\mathbf{2}}\left(\boldsymbol{c}_{\mathbf{R}} * \boldsymbol{C O}_{\mathbf{2}}\right)$ leading to the more complex model:

$\boldsymbol{F}=\beta_{0}+\beta_{1} \boldsymbol{c}_{\mathbf{R}}+\beta_{2} \boldsymbol{C O}_{2}+\beta_{3}\left(\boldsymbol{c}_{\mathbf{R}} * \boldsymbol{C O}_{2}\right)+\boldsymbol{\varepsilon} \quad($ Model 2)

with $\beta_{2}$ and $\beta_{3}$ again reflecting the corresponding regression coefficients. Again, $R^{2}$ provides information about the quality of the model. Furthermore, p-values indicate the significance for the exchange triggers $\boldsymbol{C O}_{\mathbf{2}}$ and $\boldsymbol{c}_{\mathbf{R}} * \boldsymbol{C O}_{2}$. Here, the values of type III sum of squares (SS) are taken into account. If the influence of $\boldsymbol{C O}_{\mathbf{2}}$ is significant, both groups within one data set (one tree) are different. Significance concerning the interaction indicates that both groups within the analyzed data set are significantly different if projected to the $\mathrm{y}$-axis $(\boldsymbol{F})$. Finally, interaction may also indicate differences of the linear slope.

Besides these analyses regarding the linear relationship of exchange rate and COS concentration, several mean value comparisons were performed by the two-sided Student's ttest. The null hypothesis that no difference exists between the two means $\mu_{1}$ and $\mu_{2}$ was tested against the alternative with an existing difference, i.e.,

$\mathrm{H}_{0}: \mu_{1}=\mu_{2}$ versus $\mathrm{H}_{1}: \mu_{1} \neq \mu_{2}$.

Again, corresponding p-values indicate the significance of the results. A p-value less than $5 \%$ indicates a significant difference. 
Table 1. Schedule of measurements of trees grown constantly under the indicated $\mathrm{CO}_{2}$ regimes beginning in March 1998. Three individuals of each tree species in each growth regime were consecutively measured.

\begin{tabular}{lrl}
\hline & $\begin{array}{r}\mathrm{CO}_{2} \text { regime } \\
(\mathrm{ppm})\end{array}$ & $\begin{array}{l}\text { Measurement } \\
\text { window }\end{array}$ \\
\hline Fagus sylvatica & 350 & 27 August-15 September 1998 \\
800 & 15 September-23 September 1998 \\
350 & 5 July-13 July 1999 \\
800 & 8 June-28 June 1999 \\
350 & 8 October-1 November 1999 \\
800 & 13 September-7 October 1999 \\
\hline Quercus ilex & 350 & 8 June-20 August 1998 \\
& 800 & 21 July-4 August 1998 \\
350 & 29 April-5 May 1999 \\
800 & 19 May-1 July 1999 \\
350 & 17 December-26 December 1999 \\
800 & 7 February-17 February 2000 \\
\hline
\end{tabular}

The group comparisons were carried out with each tree and for each measuring period comparing the influence of the two $\mathrm{CO}_{2}$ concentrations. Thus, means of leaf conductance, $\mathrm{CA}$ and the deposition velocities of $\mathrm{COS}$ and $\mathrm{CO}_{2}$ were compared.

All above mentioned statistical analyses were performed with SAS, Version 9.1.

The differences of the point of uptake affinity (PUA), a new term to understand the correlation between COS concentration and uptake in the absence of a compensation point, were checked by the $95 \%$ confidence intervals of the linear model 1 for $F=0$ (Sigma Plot 11).

\section{Results}

\subsection{Leaf conductances, deposition velocities and CA activities}

Elevated $\mathrm{CO}_{2}$ was expected to affect several physiological parameters reflecting gas exchange under acclimation conditions. Table 2 gives an overview of leaf conductances $\left(\mathrm{COND} ; \mathrm{mmol} \mathrm{m}^{-2} \mathrm{~s}^{-1}\right), \mathrm{CO}_{2}$ and $\mathrm{COS}$ deposition velocities $\left(V_{\mathrm{d}} ; \mathrm{mm} \mathrm{s}^{-1}\right.$; quotient exchange rate/concentration and from linear model 1 , respectively), as well as carbonic anhydrase activities of trees grown under the indicated $\mathrm{CO}_{2}$ regimes as observed in the course of the three years experiment. European beech grown under $800 \mathrm{ppm} \mathrm{CO}_{2}$ exhibited significantly reduced leaf conductances $\left(\mathrm{H}_{2} \mathrm{O}\right)$ in $\mathrm{Au}-$ gust/September 1998 and September/October 1999 and significantly increased conductances in June/July 1999. Holm oak exhibited significantly lower conductances for the JuneAugust 1998 data only. $\mathrm{CO}_{2}$ deposition velocities $\left(V_{\mathrm{dCO}_{2}}\right)$ exhibited a more consistent behavior. In all cases we found significantly lower $V_{\mathrm{dCO}_{2}}$ under elevated $\mathrm{CO}_{2}$ with pvalues $<0.001$.
Due to the variable COS concentrations, the deposition velocities for COS (Table 2) were derived from the slope of the regression line plotting the exchange data against the reference gas phase COS concentration. Generally, the $V_{\mathrm{dCOS}}$ was lower under elevated $\mathrm{CO}_{2}$. However, these differences were not significant with p-values $>0.05$ in the case of all beech data, and in the case of holm oak for the April/July 1999 data. Furthermore, it has to be noted that a general acclimation trend, i.e. a development of $V_{\mathrm{dCOS}}$ with incubation length, was not observed for beech, whereas a steady increase in the case of holm oak under elevated $\mathrm{CO}_{2}$ might exist.

As elucidated in the introduction, the uptake of COS is based on the consumption by the enzymatic triad Rubisco, PEP-Co, and carbonic anhydrase (CA), with CA regarded as the key enzyme. Table 2 gives an overview of the amount of CA activity measured within the leaves of the tree individuals growing under elevated $\mathrm{CO}_{2}$. A decrease of the $\mathrm{CA}$ activity under elevated $\mathrm{CO}_{2}$ was found in the case of holm oak in April/July 1999 and December 1999/February 2000, although these differences were not significant.

\subsection{Correlation between COS uptake and environmental COS concentrations}

A clear increase of COS uptake was observed in relation to increasing ambient COS concentration with all trees and during all measurement times. Thus, in plotting a regression line a point of intersection with the $\mathrm{x}$-axis could be expected. However, with the exception of a few single points (Fig. 1, Fagus sylvatica Sep/Oct 1999) we never observed an emission of COS. In view of this result, we will not discuss a compensation point but regard the estimated intersection with the $\mathrm{x}$-axis as an indicator of substrate affinity in relation to the enzymatic background. We call it point of uptake affinity (PUA). Table 2 gives an overview of the ranges of PUA as derived from the regression studies; given are the intersections 


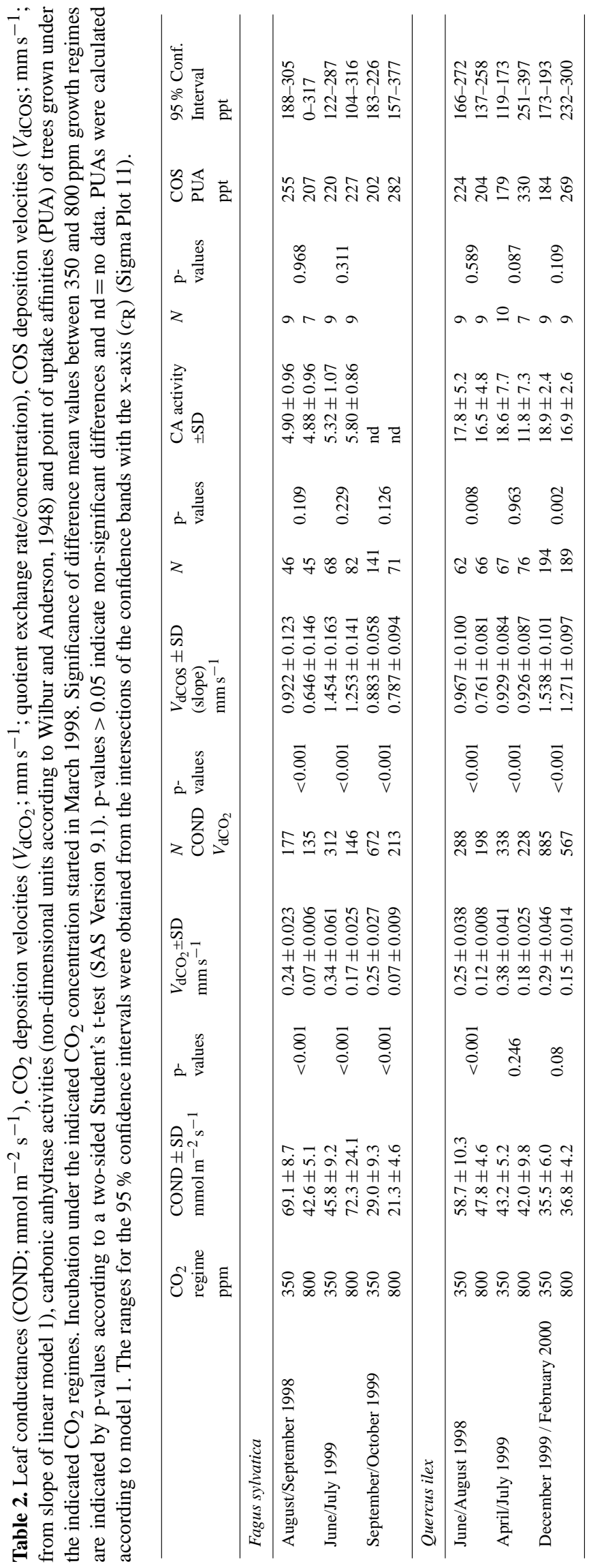




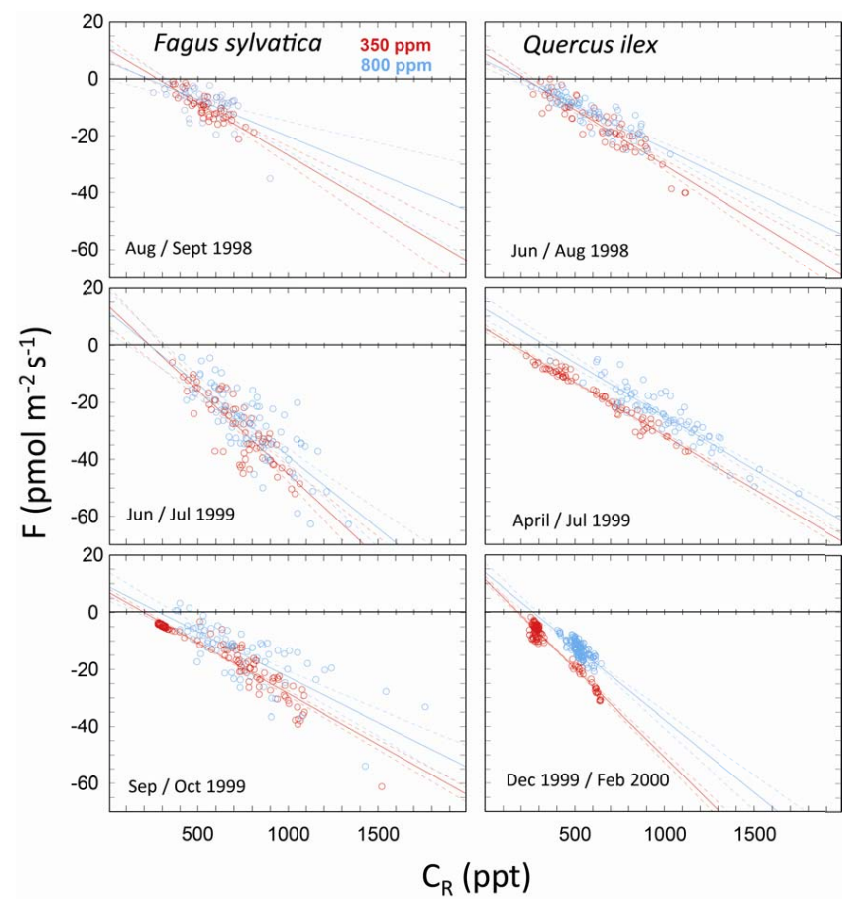

Fig. 1. Linear regression analysis of the relation between the initial COS concentration $\left(c_{\mathrm{R}}\right)$ and the uptake by European beech (Fagus sylvatica) and holm oak (Quercus ilex) growing under two different $\mathrm{CO}_{2}$ regimes (350 and $800 \mathrm{ppm}$ ) beginning in March 1998 and measured at the indicated time periods. Given are the regression lines (continuous lines) together with their $95 \%$ confidence bands (broken lines).

of the regression line with the $\mathrm{x}$-axis plus the ranges of the $95 \%$ confidence level. We observed a shift of the PUA towards higher values during continuous growth of the trees under elevated $\mathrm{CO}_{2}$. In the case of holm oak (Quercus ilex), this shift is clearly demonstrated for two consecutive measurement periods 1999 and 1999/2000 (Fig. 1; Table 2). European beech (Fagus sylvatica) showed a similar trend related to the growing conditions within the measurement period September/October 1999; however, the confidence intervals still overlap, indicating non-significance. Unfortunately, no data could be reported for a second year for this species due to limited growth and measurement capacities.

\subsection{Statistical significance of the differences between flux data sets}

Table 3 presents an overview on the correlation and regression analyses performed. As indicated by a Pearson's correlation coefficient $\left(P_{\mathrm{c}}\right)<-0.7$ (Table 3), except for the data set with beech in $1998\left(800 \mathrm{ppm} \mathrm{CO} \mathrm{CO}_{2}\right)$, we observed a strong linear relationship between the exchange flux $(F)$ and the initial COS concentration as determined within the empty reference cuvette $\left(c_{\mathrm{R}}\right)$. Even for the exception, Fagus sylvatica at $800 \mathrm{ppm}$ with a $P_{\mathrm{c}}$ of -0.58 , we also detected a correlation.
This result demonstrates that the linear model 1 is able to describe the variances well.

Adding the long-term growth regimes $\left(\mathrm{CO}_{2}\right.$ concentration), as described by linear model 2 (Table 3 ), drastically changes $R^{2}$. As expected, the new values lie between those separated according to their growth regime (see Table 3 ). The best description was found in the case of holm oak for the year $1999\left(R^{2}=0.91\right)$ followed by holm oak in the year 2000 $\left(R^{2}=0.88\right)$. For all other data sets, the variances are within the range of 51 to $83 \%$. Regarding the type III SS values, only in the case of holm oak (1999) could a highly significant difference between the 350 and $800 \mathrm{ppm}$ regimes be found $(p<0.001)$. In the case of all other measurement sets, such an acclimation could not be statistically proved, though sometimes a trend may be discussed. However, often both data clouds overlap at the start of the incubation, and in the case of beech during the whole observation time (Fig. 1). All together we may summarize that a statistically sound difference between the exchange behaviors of trees growing under elevated as compared to normal $\mathrm{CO}_{2}$ was only found for the holm oak after one year of acclimation. In this special case the linear slope is nearly identical indicating very similar deposition velocities, whereas the two other oak data sets exhibit significantly different slopes. For beech trees identical slopes cannot be excluded because of the large p-values.

\subsection{Global impact}

Deposition velocities $\left(V_{\mathrm{d}}\right)$ are key for calculating fluxes and for estimating $\mathrm{COS}$ uptake versus $\mathrm{CO}_{2}$ uptake rates to derive GPP related global sink estimates. We recalculated the global sink strength of vegetation based on our previous estimation (Sandoval-Soto et al., 2005) taking only those ecosystems into consideration with the two tree species as major contributors. Furthermore, we assume that the GPP is not altered because of physiological acclimation (decrease of enzymatic activities and stomatal aperture). With this approach, we estimate a decrease in the COS sink strength due to changed deposition velocities and enzymatic activities from 0.367 0.687 to $0.337-0.542 \mathrm{Tg} \mathrm{a}^{-1}$, representing a decrease of 8 $21 \%$.

\section{Discussion}

\subsection{Leaf conductances, deposition velocities and CA activities}

Acclimation to elevated $\mathrm{CO}_{2}$ is reported to result in a reduction of the stomatal opening as a main factor (Paoletti and Gellini, 1993; Ceulemans and Mousseau, 1994; Ainsworth and Long, 2005). However, the data as presented in our study were biased by seasonal development because of the laborintensive and time consuming measurements which were spread over several weeks for each period. Thus, not all of the data compared exhibited a significant reduction of stomatal 
Table 3. Correlation (Pearson's coefficient, $\left.P_{\mathrm{c}}\right)$ and regression analysis $\left(R^{2}\right.$; see Fig. 1$)$ according to model 1 regarding the correlation between the initial COS concentration in the reference cuvette $\left(c_{\mathrm{R}}\right)$ and the exchange flux (SAS Version 9.1). Regression analysis $\left(R^{2}\right.$; see Fig. 1) according to model 2 regarding the correlation between the initial COS concentration in the reference cuvette $\left(c_{\mathrm{R}}\right)$ and the exchange flux. Model 2 describes the results taking into account the growth regime (SAS Version 9.1).

\begin{tabular}{|c|c|c|c|c|c|c|}
\hline \multirow[t]{3}{*}{ Plant species Year } & \multirow{3}{*}{$\begin{array}{l}\text { Growth } \\
\text { regime } \\
\mathrm{CO}_{2}(\mathrm{ppm})\end{array}$} & \multicolumn{2}{|c|}{ Model 1} & \multicolumn{3}{|c|}{ Model 2} \\
\hline & & $P_{\mathrm{c}}$ & $R^{2}$ & $R^{2}$ & Type III SS-CO ${ }_{2}$ & Type III SS- $\mathrm{CO}_{2} * c_{\mathrm{R}}$ \\
\hline & & & & & \multicolumn{2}{|c|}{ p-values } \\
\hline Fagus sylvatica (Sep 1998) & $\begin{array}{l}350 \\
800\end{array}$ & $\begin{array}{l}-0.858 \\
-0.585\end{array}$ & $\begin{array}{l}0.736 \\
0.342\end{array}$ & 0.511 & 0.280 & 0.109 \\
\hline Fagus sylvatica (June/July 1999) & $\begin{array}{l}350 \\
800\end{array}$ & $\begin{array}{l}-0.842 \\
-0.783\end{array}$ & $\begin{array}{l}0.709 \\
0.614\end{array}$ & 0.654 & 0.775 & 0.229 \\
\hline Fagus sylvatica (Sept/October 1999) & $\begin{array}{l}350 \\
800\end{array}$ & $\begin{array}{l}-0.954 \\
-0.786\end{array}$ & $\begin{array}{l}0.910 \\
0.619\end{array}$ & 0.799 & 0.362 & 0.126 \\
\hline Quercus ilex (June/August 1998) & $\begin{array}{l}350 \\
800\end{array}$ & $\begin{array}{l}-0.917 \\
-0.878\end{array}$ & $\begin{array}{l}0.840 \\
0.770\end{array}$ & 0.831 & 0.208 & 0.008 \\
\hline Quercus ilex (May/July 1999) & $\begin{array}{l}350 \\
800\end{array}$ & $\begin{array}{l}-0.981 \\
-0.917\end{array}$ & $\begin{array}{l}0.962 \\
0.841\end{array}$ & 0.907 & $<0.001$ & 0.963 \\
\hline Quercus ilex (Dec 1999/Jan2000) & $\begin{array}{l}350 \\
800\end{array}$ & $\begin{array}{l}-0.968 \\
-0.763\end{array}$ & $\begin{array}{l}0.938 \\
0.582\end{array}$ & 0.884 & 0.182 & 0.002 \\
\hline
\end{tabular}

aperture caused by elevated $\mathrm{CO}_{2}$ (Table 2). We consider the non-significance for the evergreen species holm oak within the "winter measurements" to be a seasonal effect. Similarly, the missing significance for the April/July data may be related to different physiological activities of the oak species in the course of this pair of measurements. Contrasting the expectations, the beech data for summer 1999 showed a significant increase of stomatal conductance under elevated $\mathrm{CO}_{2}$. This increase may be understood to be caused by plant development between the June and July measurements. In July we noted a higher transpiration with all three tree individuals investigated in this case (data not shown). Nevertheless, excluding the June/July 1999 measurements for beech, the leaf conductance data indicated a decreasing trend over time in relation to the growth regime. This behavior is in close accordance with Herrick et al. (2004), who reported a decrease of stomatal conductance for sweetgum leaves under $\mathrm{CO}_{2}$ enrichment. Contrasting the conductance data, a significant decrease of the $\mathrm{CO}_{2}$ deposition velocities under elevated $\mathrm{CO}_{2}$ was observed in all cases.

The COS deposition velocities were lower under elevated $\mathrm{CO}_{2}$ in nearly all cases. However, these differences were not significant. Interestingly, with the exception of beech in June/July and September/October 1999, a steady increase of $V_{\mathrm{dCOS}}$ was found under $800 \mathrm{ppm} \mathrm{CO}_{2}$. Such a development of $V_{\mathrm{dCOS}}$ is in accordance with data observed with sweetgum (White et al., 2010) but contrasts with the behavior of loblolly pine trees as reported by the same authors. However, we should have in mind that the third measurement period for the oak species was scheduled for a winter period, which limits a consistent interpretation.

We regard the decrease of $V_{\mathrm{dCOS}}$ under elevated $\mathrm{CO}_{2}$ as a consequence of a competitive inhibition of the enzymes responsible for $\mathrm{COS} / \mathrm{CO}_{2}$ uptake by the higher number of $\mathrm{CO}_{2}$ molecules competing for the same binding site. On a first view this seems to be contrasting Stimler et al. (2010b), who reported missing cross-inhibition effects between COS and $\mathrm{CO}_{2}$. We agree that increasing $\mathrm{COS}$ does not inhibit $\mathrm{CO}_{2}$ uptake, which seems to be reasonable comparing ppm with ppt. However, the effect of high $\mathrm{CO}_{2}$ on the metabolism of COS does not really support their view. Regarding Fig. 6 in Stimler et al. (2010b), we got the impression that the increasing $\mathrm{CO}_{2}$ in all assays led to a slight decrease of the COS uptake beginning at $450 \mathrm{ppm} \mathrm{CO}_{2}$. Stimler et al. (2010b) themselves state that at high $\mathrm{CO}_{2}$ concentration, the uptake of $\mathrm{CO}_{2}$ continued to increase whereas the uptake of COS became saturated. The authors relate this behavior to synchronization with stomatal conductance and conclude that there is no inhibitory effect of $\mathrm{CO}_{2}$ on COS uptake. The related data sets are not convincing as there is a decrease of COS uptake, and we think that a competitive inhibition cannot be excluded. We came to similar conclusions investigating the uptake of COS by decaying leaf litter (no active stomata) with decreasing uptake of COS under high respiration rates (Kesselmeier and Hubert, 2002). Furthermore, studies modeling the consumption of COS by carbonic anhydrase (Schenk et al., 2004; Notni et al., 2007) demonstrate the similarity of the enzymatic handling of COS as compared to $\mathrm{CO}_{2}$. If we have to assume that $\mathrm{CO}_{2}$ and $\mathrm{COS}$ compete for the same binding site, we cannot exclude 
competitive inhibition, especially as we measured under an $800 \mathrm{ppm}$ growth regime.

The determination of the CA enzymatic activities under current and elevated $\mathrm{CO}_{2}$ did not show a clear result. Whereas beech did not show any acclimation, the holm oak data may be discussed indicating a long-term acclimation with a decrease of CA activity under elevated $\mathrm{CO}_{2}$, which fits into the overall picture that acclimation of CA can be expected (Sage, 2002). Furthermore, the difference between European beech and holm oak is striking. The oak exhibits a three times higher amount of CA.

\subsection{Correlation between $\operatorname{COS}$ uptake and environmental COS concentrations}

We found a clear correlation of the COS uptake with ambient COS concentrations. Thus, an intersection of the regression line with the x-axis would reflect a so-called compensation point, which is defined as the result of the balance of consumption and production with a net exchange of zero (Conrad, 1994). Hence, an increase of the COS compensation point may be understood as a decrease of metabolic consumption, caused by a decrease of the enzyme affinity towards the substrate or a decrease of the enzymatic activity itself. As we observed a potential for decrease in the case of Quercus ilex (see above), an analysis of the flux data became highly interesting. Although not significant, CA activity after growth under high $\mathrm{CO}_{2}$ levels tends to be lower than under normal levels (Table 2), though this acclimation seemed to decrease in the second year. However, we did not observe any emission of COS under our experimental conditions with $350 \mathrm{ppm} \mathrm{CO}_{2}$, and only a few data points under elevated $\mathrm{CO}_{2}$. Hence, as production of COS is missing, we are referring in this paper to a "virtual" compensation point, i.e. the intersection point of the extrapolated regression line of linear model 1 with the $\mathrm{x}$-axis (Fig. 1). We propose to call this a point of uptake affinity (PUA), reflecting substrate affinity and enzyme activity. It can be noted that the PUA changes under elevated $\mathrm{CO}_{2}$ (Table 2). For holm oak the data provide evidence that it adapts to elevated $\mathrm{CO}_{2}$ levels by shifting the PUA, indicating a decrease of the COS uptake capacity induced by high $\mathrm{CO}_{2}$ levels under long-term conditions. Beech, however, exhibits only a trend but supports a similar interpretation.

\subsection{Global impact}

Based on the few tree species investigated under elevated $\mathrm{CO}_{2}$ so far, this approach has to be regarded as very preliminary. However, it contributes to the discussion of how elevated $\mathrm{CO}_{2}$ might affect the global COS budget and balance (White et al., 2010). The increase of $\mathrm{CO}_{2}$ levels, impacting the enzymatic adjustment (CA, Rubisco, PEP-Co) of plants, may cause a decrease of COS uptake as indicated by the $V_{\mathrm{dCOS}}$ based estimates and the potential shift of PUA.
As a consequence, the atmospheric COS level may rise and cause an increase of the direct radiative forcing by this trace gas. However, this potential contribution to global warming is counterbalanced by the cooling effect of the COS derived stratospheric sulfate aerosol (Brühl et al., 2012). Our estimates of a decrease of the COS sink strength of vegetation, correcting the Sandoval-Soto et al. (2005) database, range between $8-21 \%$. This estimate is highly dependent on the potential increase of anthropogenic sources. Such an increase is discussed based on reports by Montzka et al. (2004) and Aydin et al. (2008) indicating that present COS levels of $500 \mathrm{ppt}$ are greatly increased over preindustrial levels with a drastic increase of $200 \mathrm{ppt}$ in 19th and 20th centuries. With regard to such a steep increase which resembles that of the $\mathrm{CO}_{2}$ record, the potential decrease by the acclimation of the metabolic background of COS uptake could be expected to be balanced by a higher uptake rates due to higher substrate availability.

\section{Conclusions}

Growth of two European tree species under elevated $\mathrm{CO}_{2}$ for nearly two years resulted in changes of the exchange patterns for $\mathrm{CO}_{2}$ and $\mathrm{COS}$, which in case of Quercus ilex supports the hypothesis that elevated $\mathrm{CO}_{2}$ may lead to a reduction of the COS uptake capacity. Beech exhibited a significant decrease in leaf conductance under elevated $\mathrm{CO}_{2}$, accompanied by small and insignificant decreases of $V_{\mathrm{dCOS}}$. In contrast, holm oak exhibited no significant decrease of leaf conductance for 1999 and the winter values as well, but nevertheless a significant decrease of $V_{\mathrm{dCOS}}$ in June/August 1998 and December 1999/February 2000. Within this picture, it seems to be of interest that holm oak was found to have a 3-4 times higher CA activity and appears to be more sensitive to elevated $\mathrm{CO}_{2}$. Furthermore, in the case of holm oak a significant shift of COS point of uptake affinity (PUA) was found. Such a shift may be regarded as a result of a complex mixture of driving forces, such as substrate availability depending on changes in gas concentrations and leaf conductances, and the influence of enzymatic activities depending on the amount of the active enzyme and its substrate affinity. Under elevated $\mathrm{CO}_{2}$ we expect a decrease of enzyme activity of CA. Also, changes caused by competitive inhibition (increasing $\mathrm{CO}_{2}$ ) can be expected. The results support the hypothesis that an acclimation of plants to a higher $\mathrm{CO}_{2}$ level by decreasing their enzymatic capacity for $\mathrm{CO}_{2}$ exchange will decrease the COS uptake, though an anthropogenic COS increase might neutralize this effect. Nevertheless, a visible decrease of the metabolic capacity for consuming COS should be detectable in form of an increase of the PUA. The data presented in our study support this hypothesis, though the database of two tree species is limited, our study was too short, and it was biased by plant development due to the time consuming measurements. Furthermore, it is an open question as to how 
far this change in COS uptake is caused only by a decrease in CA activity, or also by adaptation of other enzymes such as PEP-Co and Rubisco. Answers to these questions may be found by continuous field investigations within Free Atmospheric Carbon Enrichment (FACE) sites, which offer advantages such as more natural conditions as compared to growth chamber incubation. FACE sites are suitable for more continuous and simultaneous measurements to investigate the relationships between exchange fluxes, atmospheric concentration and incubation history, and plant exchange regulations and metabolic capacities. Furthermore, modern online analytic techniques for COS determination (Stimler et al., 2010a, 2011) will add insight into these exchange processes in real time and avoid biases by seasonal development.

Acknowledgements. We gratefully acknowledge financial support from Max Planck Society. L. S. was supported by a DAAD grant. The authors thank Tracey W. Andreae for help with the manuscript. We further thank the two unknown referees as well as the editor. Their comments helped to improve the quality of the paper significantly.

The service charges for this open access publication have been covered by the Max Planck Society.

Edited by: G. Wohlfahrt

\section{References}

Ainsworth, E. A. and Long, S. P.: What have we learned from 15 years of free-air $\mathrm{CO}_{2}$ enrichment (FACE)?, A meta-analytic review of the responses of photosynthesis, canopy properties and plant production to rising $\mathrm{CO}_{2}$, New Phytologist, 165, 351-372, 2005.

Andreae, M. O. and Crutzen, P. J.: Atmospheric aerosols: Biogeochemical sources and role in atmospheric chemistry, Science, 276, 1052-1056, 1997.

Aydin, M., Williams, M. B., Tatum, C., and Saltzman, E. S.: Carbonyl sulfide in air extracted from a South Pole ice core: a 2000 year record, Atmos. Chem. Phys., 8, 7533-7542, doi:10.5194/acp-8-7533-2008, 2008.

Bandy, A. R., Thornton, D. C., Scott, D. L., Lalevic, M., Lewis, E. E., and Driedger III, A. R.: A time series for carbonyl sulfide in the Northern Hemisphere, J. Atmos. Chem., 14, 527-534, 1992.

Barkley, M. P., Palmer, P. I., Boone, C. D., Bernath, P. F., and Suntharalingam, P.: Global distributions of carbonyl sulfide in the upper troposphere and stratosphere, Geophys. Res. Lett., 35, L14810, doi:10.1029/2008GL034270, 2008.

Barnes, I., Becker, K. H., and Patroescu, I.: The tropospheric oxidation of dimethyl sulfide: A new source of carbonyl sulfide. Geophys. Res. Lett., 21, 2389-2392, 1994.

Brühl, C., Lelieveld, J., Crutzen, P. J., and Tost, H.: The role of carbonyl sulphide as a source of stratospheric sulphate aerosol and its impact on climate, Atmos. Chem. Phys., 12, 1239-1253, doi:10.5194/acp-12-1239-2012, 2012.

Campbell, J. E., Carmichael, G. R., Chai, T., Mena-Carrasco, M., Tang, Y., Blake, D. R., Blake, N. J., Vay, S. A., Collatz, G. J.,
Baker, I., Berry, J. A., Montzka, S. A., Sweeney, C., Schnoor, J. L., and Stanier, C. O.: Photosynthetic control of atmospheric carbonyl sulfide during the growing season, Science, 322, 10851088, 2008.

Cervigni, T., Teofani, F., and Bassanelli, C.: Effect of $\mathrm{CO}_{2}$ on carbonic anhydrase in Avena sativa and Zea mays, Phytochemistry, 10, 2991-2994, 1971.

Chang, C. W.: Carbon dioxide and senescence in cotton plants, Plant Physiol., 55, 515-519, 1975.

Chengelis, C. P. and Neal, R. A.: Studies of Carbonyl Sulfide Toxicity - Metabolism by Carbonic-Anhydrase, Toxicol. Appl. Pharmacol., 55, 198-202, 1980.

Ceulemans, R. and Mousseau, M.: Effects of elevated atmospheric $\mathrm{CO}_{2}$ on woody plants, New Phytol., 127, 425-446, 1994.

Coleman, J. R., Berry, J. A., Togasaki, R. K., and Grossman, A. R.: Identification of extracellular carbonic anhydrase of Chlamydomonas reinhardtii, Plant Physiol., 76, 472-477, 1984.

Conrad, R.: Compensation concentration as a critical variable for regulating the flux of trace gases between soil and atmosphere, Biogeochem., 27, 155-170, 1994.

Conrad, R. and Meuser, K.: Soils contain more than one activity consuming carbonyl sulfide, Atmos. Environ., 34, 3635-3639, 2000.

Crutzen, P. J.: The possible importance of CSO for the sulfate layer of the stratosphere, Geophys. Res. Lett., 3, 73-76, 1976.

Drake, B. G., Gonzàlez-Meler, M. A., and Long, S. P.: More efficient plants: A Consequence of Rising Atmospheric CO2?, Annu. Rev. Plant Physiol. Plant Mol. Biol., 48, 609-639, 1997.

Herrick, J. D., Maherali, H., and Thomas, R. B.: Reduced stomatal conductance in sweetgum (Liquidambar styraciflua) sustained over long-term $\mathrm{CO}_{2}$ enrichment, New Phytologist 162, 387-396, 2004.

Junge, C. E., Chagnon, C. W., and Manson, J. E.: Stratospheric aerosols, J. Meteorol., 18, 81-108, 1961.

Kettle, A. J., Kuhn, U., von Hobe, M., Kesselmeier, J., and Andreae, M. O.: Global budget of atmospheric carbonyl sulphide: Temporal and spatial variations of the dominant sources and sinks, J. Geophys. Res., 107, 4658, doi:10.1029/2002JD002187, 2002.

Khalil, M. A. K. and Rasmussen, R. A.: Global sources, lifetimes and mass balances of OCS and CS2 in the Earth's atmosphere, Atmos. Environ., 18, 1805-1812, 1984.

Kesselmeier, J. and Hubert, A.: Exchange of volatile reduced sulphur compounds between leaf litter and the atmosphere, Atmos. Environ., 36, 4679-4686, 2002.

Kesselmeier, J. and Merk, L.: Exchange of Carbonyl Sulfide (COS) between Agricultural Plants and the Atmosphere: Studies on the Deposition of COS to Peas, Corn and Rapeseed, Biogeochem., 23, 47-59, 1993.

Kesselmeier, J., Meixner, F. X., Hofmann, U., Ajavon, A., Leimbach, S., and Andreae, M. O.: Reduced sulfur compound exchange between the atmosphere and tropical tree species in southern Cameroon, Biogeochem., 23, 23-45, 1993.

Kesselmeier, J., Schäfer, L., Ciccioli, P., Branceleoni, E., Cecinato, A., Frattoni, M., Foster, P., Jacob, V., Denis, J., Fugit, J. L., Dutaur, L., and Torres, L.: Emission of monoterpenes and isoprene from a Mediterranean oak species Quercus ilex L. measured within the BEMA (Biogenic Emissions in the Mediterranean Area) project, Atmos. Environ., 30, 1841-1850, 1996. 
Kesselmeier, J., Teusch, N., and Kuhn, U.: Controlling variables for the uptake of atmospheric carbonyl sulfide (COS) by soil, J. Geophys. Res.-Atmos., 104, 11577-11584, 1999.

Kettle, A. J., Kuhn, U., von Hobe, M., Kesselmeier, J., and Andreae, M. O.: Global budget of atmospheric carbonyl sulphide: Temporal and spatial variations of the dominant sources and sinks, J. Geophys. Res., 107, 4658, doi:10.1029/2002JD002187, 2002.

Kuhn, U. and Kesselmeier, J.: Environmental variables controlling the uptake of carbonyl sulfide by lichens, J. Geophys. Res., 105, 26783-26792, 2000.

Kuhn, U., Wolf, A., Gries, C., Nash, T. H., and Kesselmeier, J.: Field measurements on the exchange of carbonyl sulfide between lichens and the atmosphere, Atmos. Environ., 34, 4867-4878, 2000.

Kjellström, E.: A three-dimensional global model study of carbonyl sulfide in the troposphere and the lower stratosphere, J. Atmos. Chem., 29, 151-177, 1998.

Lehmann, S. and Conrad, R.: Characteristics of turnover of carbonyl sulfide in four different soils, J. Atmos. Chem., 23, 193-207, 1996.

Majeau, N. and Coleman, J. R.: Effect of $\mathrm{CO}_{2}$ on carbonic anhydrase and ribulose-1,5-bisphosphate carboxylase/oxygenase expression in pea, Plant Physiol. 112, 569-574, 1996.

Mihalopoulos, N., Putaud, J. P., Nguyen, B. C., and Belviso, S.: Annual variation of atmospheric carbonyl sulfide in the marine atmosphere in the southern Indian Ocean, J. Atmos. Chem., 13, 73-82, 1991.

Montzka, S. A., Aydin, M., Battle, M., Butler, J. H., Saltzman, E. S., Hall, B. D., Clarke, A. D., Mondeel, D., and Elkins, J. W.: A 350-year atmospheric history for carbonyl sulfide inferred from Antarctic firn air and air trapped in ice, J. Geophys. Res., 109, D22302, doi:10.1029/2004JD004686, 2004.

Montzka, S. A., Calvert, P., Hall, B. D., Elkins, J. W., Conway, T. J., Tans, P. P., and Sweeney, C.: On the global distribution, seasonality, and budget of atmospheric carbonyl sulfide and some similarities with $\mathrm{CO}_{2}$, J. Geophys. Res., 112, D09302, doi:10.1029/2006JD007665, 2007.

Moore, B. D., Cheng, S. H., Sims, D., and Seemann, J. R.: The biochemical and molecular basis for photosynthetic acclimation to elevated atmospheric $\mathrm{CO}_{2}$. Plant Cell Environ., 22, 567-582, 1999.

Mu, Y., Geng, C., Wang, M., Wu, H., Zhang, X., and Jiang, G.: Photochemical production of carbonyl sulphide in precipitation, J. Geophys. Res., 109, D13301, doi:10.1029/2003JD004206, 2004.

Notholt, J., Kuang, Z., Rinsland, C. P., Toon, G. C., Rex, M., Jones, N., Albrecht, T., Deckelmann, H., Krieg, J.,Weinzierl, C., Bingemer, H., Weller, R., and Schrems, O.: Enhanced upper tropical tropospheric COS: Impact on the stratospheric aerosol layer, Science, 300, 307-310, 2003.

Notni, J., Schenk, S., Protoschill-Krebs, G., Kesselmeier, J., and Anders, E.: The missing link in COS metabolism: A model study on the reactivation of carbonic anhydrase from its hydrosulfide analogue, ChemBioChem, 8, 530-536, 2007.

Paoletti, E. and Gellini, R.: Stomatal density variation in beech and holm oak leaves collected over the last 200 years, Acta Oecologia, 14, 173-178, 1993.

Peet, M. M., Huber, S. C., and Patterson, D. T.: Acclimation to high$\mathrm{CO}_{2}$ in moneoecious cucumbers, II. Carbon exchange rates, enzyme activities, and starch and nutrient concentrations, Plant
Physiol., 80, 63-67, 1986.

Peuser, D. and Wild, A.: Environmental simulation, Nachr. Chem. Tech. Lab., 44, 289-294, doi:10.1002/nadc.19960440316, 1996.

Peuser, D., Lenz, C., and Wild, A.: Umweltsimulation für Pflanzen in Klimakammern: eine kostengünstige Lösung mittels industrieller Standardsoftware und eines selbstentwickelten $\mathrm{CO}_{2}$-Analysators, Forschungsmagazin der Johannes GutenbergUniversität Mainz, Sonderausgabe aus Anlass der Hannover Messe, 34-42, März/April 1995, 1995.

Porter, M. A. and Grodzinski, B.: Regulation of chloroplastic carbonic anhydrase, Plant Physiol., 72 , 604-605, 1983.

Possell, M. and Hewitt, N. C.: Gas exchange and photosynthetic performance of the tropical tree Acacia nigrescens when grown in different $\mathrm{CO}_{2}$ concentrations, Planta, 229, 837-846, 2009.

Protoschill-Krebs, G. and Kesselmeier, J.: Enzymatic pathways for the consumption of carbonyl sulphide (COS) by higher plants, Botanica Acta, 105, 206-212, 1992.

Protoschill-Krebs, G., Wilhelm, C., and Kesselmeier, J.: The consumption of carbonyl sulphide by carbonic anhydrase (CA) of Chlamydomonas reinhardtii grown under different $\mathrm{CO}_{2}$ regimes, Botanica Acta, 108, 445-448, 1995.

Protoschill-Krebs, G., Wilhelm, C., and Kesselmeier, J.: Consumption of carbonyl sulphide by carbonic anhydrase (CA) isolated from Pisum sativum, Atmos. Environ., 30, 3151-3156, 1996.

Rogers, A. and Ellsworth, D. S.: Photosynthetic acclimation of $\mathrm{Pi}$ nus taeda (loblolly pine) to long-term growth in elevated $\mathrm{pCO} 2$ (FACE), Plant, Cell Environ., 25, 851-858, 2002.

Sage, R. F.: How terrestrial organisms sense, signal, and respond to carbon dioxide, Integ. and Comp. Biol., 42, 469-480, 2002.

Sandoval-Soto, L., Stanimirov, M., von Hobe, M., Schmitt, V., Valdes, J., Wild, A., and Kesselmeier, J.: Global uptake of carbonyl sulfide (COS) by terrestrial vegetation: Estimates corrected by deposition velocities normalized to the uptake of carbon dioxide $\left(\mathrm{CO}_{2}\right)$, Biogeosciences, 2, 125-132, doi:10.5194/bg-2-1252005, 2005.

Schäfer, L., Kesselmeier, J., and Helas, G.: Formic and Acetic acid emission from conifers measured with a "cuvette" technic, in: CeC Air Pollution Research 39: Field Measurements and Interpretation of Species Related to Photooxidants and Acid Deposition, edited by: Angeletti, G., Beilke, S., and Slanina, J., 319323, Eur. Comm., Brussels, 1992.

Schenk, S., Kesselmeier, J., and Anders, E.: How does the exchange of one oxygen atom with sulfur affect the catalytic cycle of carbonic anhydrase?, Chem. Eur. J., 10, 3091-3105, 2004.

Seibt, U., Kesselmeier, J., Sandoval-Soto, L., Kuhn, U., and Berry, J. A.: A kinetic analysis of leaf uptake of COS and its relation to transpiration, photosynthesis and carbon isotope fractionation, Biogeosciences, 7, 333-341, doi:10.5194/bg-7-333-2010, 2010.

Simmons, J. S., Klemedtsson, L., Hultberg, H., and Hines, M. E.: Consumption of atmospheric carbonyl sulfide by coniferous boreal forest soils, J. Geophys. Res., 104, 11569-11576, 1999.

Smeulders, M. J., Barends, T. R. M., Pol, A., Scherer, A., Zandvoort, M. H., Udvarhelyi, A., Khadem, A. F., Menzel, A., Hermans, J., Shoeman, R. L., Wessels, H. J. C. T., van den Heuvel, L. P., Russ, L., Schlichting, I., Jetten, M. S. M., den Camp, H. J. M. O.: Evolution of a new enzyme for carbon disulphide conversion by an acidothermophilic archaeon, Nature, 478, 412-416, doi:10.1038/nature10464, 2011. 
Stimler, K., Nelson, D., and Yakir, D.: High precision measurements of atmospheric concentrations and plant exchange rates of carbonyl sulfide using mid-IR quantum cascade laser, Glob. Change Biol., 16, 2496-2503, 2010a.

Stimler, K., Montzka, S. A., Berry, J. A., Rudich, Y., and Yakir, D.: Relationships between carbonyl sulfide (COS) and $\mathrm{CO}_{2}$ during leaf gas exchange, New Phytologist, 186, 869-878, 2010b.

Stimler, K., Berry, J. A., Montzka, S. A., and Yakir, D.: Association between carbonyl sulfide uptake and its $18 \Delta$ during gas exchange in C3 and C4 leaves, Plant Physiol., 157, 509-517, 2011.

Stitt, M. and Krapp, A.: The interaction between elevated carbon dioxide and nitrogen nutrition: the physiological and molecular background, Plant Cell Environ., 22, 583-621, 1999.

Spencer, K. G., Kimpel, D. L., Fisher, M. L., Togasaki, R. K., and Miyachi, S.: Carbonic anhydrase in Chlamydomonas reinhardtii, II. Requirements for carbonic anhydrase induction, Plant Cell Physiol., 24/2, 301-304, 1983.

Suntharalingam, P., Kettle, A. J., Montzka, S. M., and Jacob, D. J.: Global 3-D model analysis of the seasonal cycle of atmospheric carbonyl sulfide: Implications for terrestrial vegetation uptake, Geophys. Res. Lett., 35, L19801, doi:10.1029/2008GL034332, 2008.

Thiess, A. M., Hey, W., Hofmann, H. T., and Oettel, H.. Zur Toxicität des Kohlenoxysulfids, Archive. Toxicol., 23, 253-263, 1968.

Van Diest, H. and Kesselmeier, J.: Soil atmosphere exchange of carbonyl sulfide (COS) regulated by diffusivity depending on waterfilled pore space, Biogeosciences, 5, 475-483, doi:10.5194/bg-5475-2008, 2008.
Von Caemmerer, S. and Farquhar, G. D.: Some relationships between the biochemistry of photosynthesis and the gas exchange of leaves, Planta, 153, 376-387, 1981.

Von Hobe, M., Kuhn, U., van Diest, H., Sandoval-Soto, L., Kenntner, T., Helleis, F., Yonemura, S., Andreae, M. O., and Kesselmeier, J.: Automated in-situ analysis of volatile sulphur gases using a Sulphur Gas Analyser (SUGAR) based on cryogenic trapping and gas-chromatographic separation, Int. J. Environ. Anal. Chem., 88, 303-315, 2008.

Watts, S. F.: The mass budgets of carbonyl sulfide, dimethyl sulfide, carbon disulfide and hydrogen sulfide, Atmos. Environ., 34, 761779, 2000.

White, M. L., Zhou, Y., Russo, R. S., Mao, H., Talbot, R., Varner, R. K., and Sive, B. C.: Carbonyl sulfide exchange in a temperate loblolly pine forest grown under ambient and elevated CO2, Atmos. Chem. Phys., 10, 547-561, doi:10.5194/acp-10-547-2010, 2010.

Wilbur, K. M. and Anderson, N. G.: Electrometric and colorimetric determination of carbonic anhydrase, J. Biol. Chem., 176, 147$154,1948$.

Wohlfahrt, G., Brilli, F., Hörtnagl, L., Xu, X., Bingemer, H., Hansel, A., and Loreto, F.: Carbonyl sulfide (COS) as a tracer for canopy photosynthesis, transpiration and stomatal conductance: potential and limitations, Plant Cell Environ., 35, 657667; doi:10.1111/j.1365-3040.2011.02451.x, 2012.

Yonemura, S., Sandoval-Soto, L., Kesselmeier, J., Kuhn, U., Von Hobe, M., Yakir, D., and Kawashima, S.: Uptake of carbonyl sulfide (COS) and emission of dimethyl sulfide (DMS) by plants, Phyton., 45, 17-24, 2005. 